\title{
A Study on Mapping Out Alliance Between Economic Growth and Foreign Direct Investment in Pakistan
}

\author{
Khawaja Asif Mehmood ${ }^{1} \&$ Sallahuddin Hassan ${ }^{1}$ \\ ${ }^{1}$ School of Economics, Finance and Banking, Universiti Utara Malaysia, Malaysia \\ Correspondence: Khawaja Asif Mehmood, School of Economics, Finance and Banking, Universiti Utara \\ Malaysia, Malaysia. E-mail: khawjaasif@bzu.edu.pk
}

Received: January 1, 2015 Accepted: January 31, 2015 Online Published: May 15, 2015

doi:10.5539/ass.v11n15p113

URL: http://dx.doi.org/10.5539/ass.v11n15p113

\begin{abstract}
Sustained economic growth is a trance of all the developing and developed countries of the world. The need is not just a fetch of economic growth rather is a realization of a fact that the why some economies that receive heavy amount of foreign capital inflows in term of foreign direct investment (FDI) still find hard to capture the economic growth targets. This research captures for the state of the position of economic growth in terms of FDI and other internal factors in Pakistan. The study is based on the time series analysis covering the range of data from 1972 to 2014. Johansen Juselius technique of co-integration is employed for the precise statistical findings. Unit root test is computed in terms of Augmented Dickey Fuller Test (ADF). Granger Causality test and Error Correction Model (ECM) is employed to test for the short-run and long-run relationships and causality between the variables selected in the equation of growth. The results of the study show that FDI and GDP possess positive association in short-run as well as in long-run. Unidirectional causality is also found on account of FDI and GDP. The study suggests that the government of Pakistan is to further pave off the ways that it already practices to attract FDI that is prerequisite for sovereign upcoming scenery of the country.
\end{abstract}

Keywords: economic growth, foreign direct investment, granger causality, inflation, labor force

\section{Introduction}

Towards an economic growth, it is believed that FDI is always to bring up positive effects (Thomas, 2008). Developing countries, like Pakistan, are always found eager in making themselves attractive towards the foreign investors. Economic growth is believed to be got, in sequel of FDI, in result of the enhancement in productivity level of the economy as well as of the transfer of the advanced technologies that contributes to the employment creation and in turn rises up the competition level (Kobrin, 2005). Khan (2007) argued that FDI is widely known as a factor that proliferate the overall growth base of the developing economies. Among the variety of channels that enable the FDI to positively affect the macroeconomic stature of their host country, the widely recognized is the process in which the technology is transferred to the recipient country. In line with the foreign capital inflows that are for sure the important sources of capital in any country, motivate the researcher(s) to execute a research on how these foreign inflows affect the growth rate of their host economy.

FDI widens the level of sale in the host country that is perhaps used for the expansion of the business. In positively pressurizing the local production base of the country, it results in bringing up allocative, productive and technical efficiency in an economy. Thus, positively contributes in the process of long term development in an economy (Khan, 2007). According to Zhang (2001), FDI is an engine of growth in terms of enhancing the rate of capital formation of the country, widening-off the employment level and indeed flourishing the manufacturing base of the host country. In the capacity of filling the previously undone gaps between savings and investments of an economy, FDI enables the receiving country to raise-up her level of investment even above the existence level of domestic saving (Hye, Shahbaz, \& Hye, 2010).

FDI is a powerful stimulator for economic growth and development. Indeed for driving national trade towards the consistent improvement in balances of payment. Thus, FDI is of profound value in term of the globalized world chain. Statistics by The World Bank [WB] and International Monetary Fund [IMF] state that since last decade, FDI has recorded for an annual growth of 9 percent at globe. The remarkable growth on account of FDI is a reason for enabling world GDP growth to have a hike of above 7 percent during 2012 to 2014. In recognizing FDI as a fueling element for growth and development, The World Economic Forum in its recent 
annual meeting of 2013-2014 declared that the global agenda of the world as a whole for next financial year will be to cater more and more ways of examining the effects and patterns of flows of FDI in both developing and developed countries.

The fact that provokes for executing research, based on the future perspective of FDI, on Pakistan is a fact that Pakistan, like other countries of the world, tries hard to attract the foreign investors. However, in line with some of the internal factors, it is incapable for the government so far to retain the pace of persistent inflows of foreign investment as were practiced in early 2000. On account of the report of "Ease of Doing Business" 2013, Pakistan is ranked at $107^{\text {th }}$ in the line of 185 countries of the world that are fascinated with such precious investment inflows. From July to April 2014, FDI flows stood at U.S Dollar (USD) 750 million in against of USD853 million during the corresponding last year.

However, the objective of this study is to investigate the effects of FDI on economic growth of Pakistan in the presence of some of the internal disrupted state of macroeconomic variables. The path of proceeding of this paper is that second section of the paper enlightens the literature work done in past in theoretical and empirical perspective. The third section gives the information about the source of data, model specification and the methodological techniques for execution of research. In subsequent to section three, next section is to elaborate the results of the findings and the last section is about the conclusion and policy recommendation.

\section{Review of the Literature}

The researches, in theoretical and empirical, have been conducted to brighten up the relationship and the degree of change in economic growth in result of a change in direct foreign investment. Khan and Khan (2011) brought the empirical evidence on accord of evaluating for how the economic growth of Pakistan is to respond against FDI inflows. Choosing the data on industry-specific effects of FDI, the sectors chosen were primary, secondary and tertiary. Based on the data from 1981 to 2008, the study was exhibited by the mean of Granger causality and panel cointegration. The results of the study found the traces of positively affected output level in response to FDI, like investigated earlier by (Hye et al., 2010). However, in terms of long run and short run causality explorations between FDI and GDP, there were found causality amongst FDI and GDP in all the three sectors, either in unidirectional or bidirectional.

In the broad spectrum, Hye et al. (2010) used FDI with official development assistance and foreign aid in exploring for their effects on economic growth of Pakistan. Official development assistance as well as foreign aid, together with FDI posted positive effects on economic growth, like Papanek (1972), Baharumshah and Thanoon (2006), unlike Mosely (1980), Rana (1987), Tsai (1994) and Ali (1993). In consequence of using autoregressive distributive lag model (ARDL) to trace for the long run effects of independent variables and ECM was fit-in to explore for the short run effects, the results found that FDI was positively related to economic growth, in long run. However, foreign aid came up to be as significantly reducing economic growth, but positive in its effects on two year lag.

In the context of East Asian countries, inclusive of China, quantitative research on finding out for the growth causing effect of foreign capital, Baharumshah and Thanoon (2006), practicing Dynamic Generalized Least square Model (DGLS), posted their empirical findings, suggesting that East Asian countries are to attract the foreign investment in order to foster their economic growth. This was suggested in consequence of significant and positive effects of FDI found on account of economic growth, in short run as well as in long run. The results were in line with Borensztein (1998) and Levine and Renelt (1992). Nevertheless, negative signs by foreign inflows were found in frame of ECM that represented as displacing domestic saving and investment in short run time period.

The important realization is not just to evaluate for how economic growth responses in sequel of FDI, rather need is to focus upon the interplay among the economic freedom and FDI. Unless the determinants of FDI, in term of economic freedom, are highlighted and indeed in good working position, there should not be any expectation(s) of raising-up of the level of economic growth (Bengoa \& Sanchez-Robles, 2003). The determinants formed to affect FDI and later that cause to influence FDI-led growth process, as highlighted by past researchers, are the market size, the economic freedom and human capital. Internal factors like of tax, exchange rate, macro-economic stability, external debt servicing, inflation, labor force participation and political stability (Tung \& Cho, 2001; Benassy-Quere, Fontagne, \& Lahreche-Revil, 2001; Lipsey, 1999; Mehmood \& Faridi, 2013). Nonetheless, trade openness and relative exchange rate were found to be as significant in their effects on FDI inflows (Hassan, Aznin, \& Hussin, 2014).

In the historic glance, the need for the foreign inflows originates in the realization that the domestic investment level is depressed due to the squeezed volume of domestic saving. This indeed makes the countries realize the 
need for the foreign capital for their economic growth (Chenery \& Strout, 1966). The flow of such vital capital, though from the outside linkage, is treated with care and perhaps considered as a mean of economic development (Papanek, 1972; Mosley, 1980; Rana, 1987; Borensztein, 1998; Levine \& Renelt, 1992; Hye et al., 2010; Khan \& Khan, 2011; Ali, 2014). In this regard, Baharumshah and Thanoon (2006) found that countries in East Asian region experience the establishment of new industries in result of FDI. All this is surely at an affirmed belief that the foreign capital is a major source for filling up the gaps between the needs of investment and the capital available for initiating investment (Mehmood \& Faridi, 2013).

Ali (2014) enquired for the effects of worker remittance and foreign debt together with that of FDI. The study was based on empirical analysis covering the data from 1972 to 2013. Granger causality test and ECM were used in supplement to Johansen Juselius technique on cointegration. The results captured the evidence that FDI retarded economic growth of Pakistan, contrary to Papanek (1973), Herzer, Klasen and Nowak-Lehmann (2006), Duasa (2007), Okodua (2009), perhaps in the long run period of time. In term of causality, unidirectional changes were found on account of FDI with economic growth, unlike of domestic investment. This took towards the conclusion that the government of Pakistan should rely upon domestic sources, i.e. domestic investment, in channelizing the country on the persistent pace of economic growth and development.

FDI inflows which are relevant to that of across the border flows of capital brings up technological advances and hence improve the state of overall investment level in economy, probably the private investment. In this respect, public investment activities also prove to be as posing positive effects on private investment activities that are being carried out in a particular economy in a given time span (Hassan, Othman, \& Karim, 2011). Investment activity is essential ingredient for economic growth. If it travels across national frontiers, it is considered as FDI, other than that in internal prospect, Hassan et al. (2011) while tracing for the effects of public sector investment and its impacts on the private sector investment in agriculture industry and trade, transport and communication and construction sector of Malaysia, found, exclusive of agriculture sector, rest of the three sectors that reciprocated with positive alignment of private and public sector investment activities.

Public investment transforms into economic growth via boosting up private investment (Hassan \& Karim, 2007). This activity of probing investment, according to Hassan and Karim (2007) contains property of increasing aggregate demand as government investment is carried on infrastructure improvement wherein private sector contributes to respond positively in reciprocation to public sector investment. Nevertheless, if the ultimate objective is to exhibit growth in business and productive activity of an economy which in sequel is transferred into economic growth and hereafter the development, the ownership structure of the businesses matters. Here, Hassan, Othman and Harun (2014) published the finding that ownership structure possesses dissimilar scale of efficiency in terms of managers and shareholders.

The research works conducted in recent times indicate FDI posting significant and positive effect on the economic growth of a country (Farkas, 2012). However, as indicated by Tung and Cho (2001), Bénassy-Quéré, Fontagné and Lahrèche-Révil (2001), Lipsey (1999) and Mehmood and Faridi (2013) about the internal economic factors, either social or economic, having strong influence in molding for the expected results of FDI on growth, the impact of FDI on growth is dependent upon the country's absorptive capacity, the level of human capital and the performance and current state of financial markets (Farkas, 2012). Growth effects of FDI depend on the domestic investment level and the trade openness (Onakoya, 2012). Thus, in conclusion investigating for the effects of FDI on economic growth, mixed trends of results are found.

\subsection{Trends of Growth and FDI in Pakistan}

Growth in economy is inevitable for the play of an influential role in globalized world. It is something that reflects the status of health of an economy. Figure 1 helps in conceptualizing that GDP growth of Pakistan remained depressed for couple of years, mainly during 2008 to 2009. However, the statistics on GDP in the booklets of The Ministry of Finance, Government of Pakistan [MFGOP] show that GDP has excelled at the level of 4.14 percent, compared with that of 3.70 percent last year. The government has acknowledged the contribution of agriculture, manufacturing and service sector altogether in possibly achieving this growth mark.

Private sector is considered as major determinant of economic growth. Likewise the same for Pakistan, private sector is contributing to the enhancement of the economic growth rate. However, private investment remained depressed in initializing new ventures initiatives in translation to the internal unfavorable conditions on account of economic and social indicators. The government of Pakistan always stands at front in attracting the foreign investors to bring-in their capital and promise investors to be benefited by the incentives that it plan to give in the shape of tax rebates, that in return should provide ease to the government in bridging savings and investment 
gaps. However in this respect, internal security and law and order issues need some concrete steps for their resolve by the government so that to pave the ways of throwing red carpet before the foreign investor.

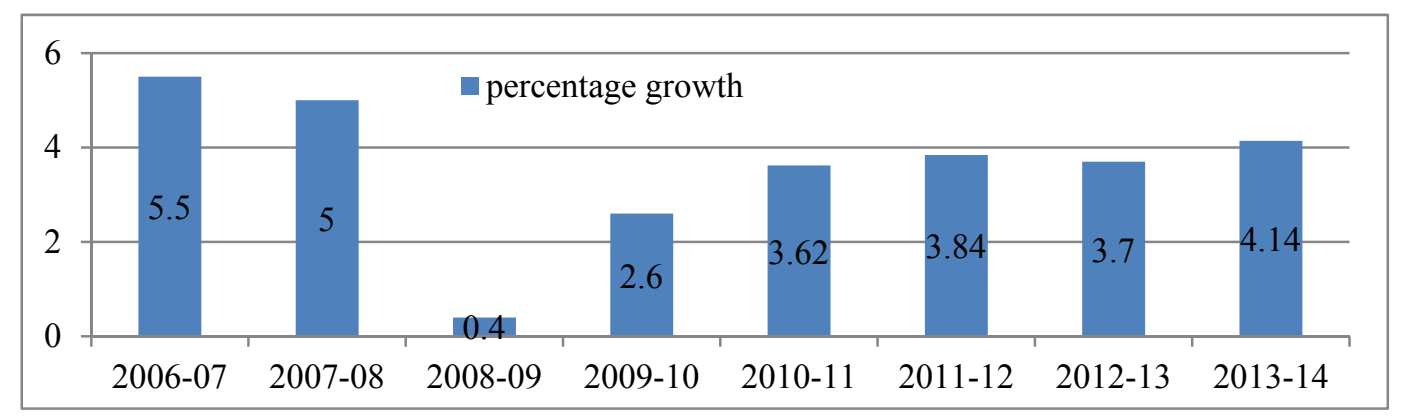

Figure 1. Trend of GDP Growth in Pakistan (Source: Economic Survey of Pakistan 2013-14)

The current going financial year has witnessed for the global recovery in term of world GDP growth rate. The economic growth is expected to accelerate in the United States and in European Union, the first world economies, indeed. Stable signs of growth are being proposed and indeed witnessed on Japan, Brazil with falling growth patterns and China as an emerging strong economy. The World Bank Global Economic Prospect report (2014) indicates for a hopeful thought on account of global economic growth rate projections. In complement to that, IMF has forecasted for global average percentage growth of 3.9 percent by 2015 . Furthermore, IMF forecast envisages that Japan is to have falling growth rates. Asian economies are expected to accompany with rise in growth to the level of 6.8 percent from that of 6.7 percent and African and South Asian countries are forecasted for better year of 2015. Table 1 gives a precise summary on account of the global economic growth rates achieved by some of the countries of the world.

Table 1. GDP growth rates of some selected countries

\begin{tabular}{cccc}
\hline Country & 2013 & 2014 & $2015\left(\mathrm{P}^{*}\right)$ \\
\hline World GDP & 3.0 & 3.6 & 3.9 \\
United States & 1.9 & 2.8 & 3.0 \\
Euro Area & -.05 & 1.2 & 1.5 \\
Japan & 1.5 & 1.4 & 1.0 \\
Developing Countries & 6.5 & 6.7 & 6.8 \\
China & 7.7 & 7.5 & 7.3 \\
Singapore & 4.1 & 3.6 & 3.6 \\
Thailand & 2.9 & 2.5 & 3.8 \\
Malaysia & 4.7 & 5.2 & 5.0 \\
India & 4.4 & 5.4 & 6.4 \\
Bangladesh & 5.8 & 6.0 & 6.5 \\
Sri Lanka & 7.3 & 7.0 & 6.5 \\
Pakistan & 3.7 & 4.14 & 5.1 \\
\hline
\end{tabular}

Source: The World Economic Out Look IMF, April 2014 *=Provisional

In imagining for the potential and capability that Pakistan has, it is quite unfortunate that FDI is not being that much attracted as otherwise. The reason(s) being are too many. If generalized, they are seen on either side i.e. social as well as economic. In first sight what comes in mind as an answer to why FDI is not that appreciably received by Pakistan are the two factors. The severe energy crises, in terms of electricity and natural gas, for first and perhaps the security threats as second. However, capital market reaches at 28913 points in contrast to 21006 points that is a reflection of growth in investment overall by 38 percent MFGOP.

The middle class of Pakistan is formed into 63 million; this large component of overall population is an envelope of workforce that is proficient in English, intelligence and hard work. Nonetheless, it possesses quantum of experienced bankers, engineers, lawyers and other professional technicians which are readily available in offering their profound and zealous services to the businesses (foreign or locally entrepreneurial). Out of the total foreign investment, USD2979 million are secured till July-April 2014 in contrast to USD1277 million last fiscal year. 
As appear to be as evident in Table 2 that major partner in injecting the FDI in Pakistan is China. However, comparing the stature of FDI from 2012 to 2013, there has been recorded a fall of USD39 million. Same downtrend is found on account of Australia, Austria, Germany and Malaysia. It is commendable to receive additional inward investments from Japan, Norway, Saudi Arabia, Switzerland and United Kingdom, during the same arena of time.

Table 2. Flow of FDI to Pakistan from selected countries

\begin{tabular}{ccc}
\hline Country & \multicolumn{2}{c}{ Flow of FDI (USD million) } \\
\cline { 2 - 3 } & 2012 & 2013 \\
\hline Australia & 45.8 & 24.5 \\
Austria & 69.1 & 53.3 \\
Bahrain & 17.4 & 1.7 \\
China & 126.1 & 90.7 \\
Germany & 28.1 & 9.5 \\
Italy & 200.5 & 199.4 \\
Japan & 31.0 & 34.5 \\
Malaysia & 9.7 & 0.9 \\
Norway & -275.0 & -258.4 \\
Saudi Arabia & -79.8 & 3.3 \\
Switzerland & 144.5 & 161.1 \\
United Kingdom & 177.8 & 585.6
\end{tabular}

Source: The State Bank of Pakistan (2013-14)

\section{Data Source, Methodology and Specification of the Economic Model}

\subsection{Source of the Data}

The data from 1972 to 2014 on variables opted in this study is collected from the sources of Economic Survey of Pakistan issued by (MFGOP) and secondly the information on some variables is relied on the data base of The State Bank of Pakistan. Both of the two data bases are authentic in the sense that are run and published under the Federal Government of Pakistan.

\subsection{Research Methodology}

This research bases upon the multiple regression technique of Johansen and Juselius (1990) in line of tracing the long-run relationship among the variables chosen in the study. Moreover, ECM is employed to check for the short-run dynamics between the right sided and left sided variables. Granger (1969) causality test is exercised for the export of information regarding the run of causality between the variables. Nonetheless unit root test, as development by Dickey and Fuller (1979) is used in order to check for the status of stationarity of the data on each variable.

\subsection{Specification of the Model}

Like Chaudhry, Malik and Faridi (2010), studies that capture for the effects of the variables on economic growth mainly begin with the model of Solow (1956). In the same perspective, taking expression from production function version of Cobb Douglas, the model of growth in general form may be written as appear in Equation [1]

$$
\mathcal{Y}_{t}=\mathcal{A}_{t} \mathcal{K}_{t}^{\alpha} \mathcal{H}_{t}^{\beta} \mathcal{L}_{t}^{1-\alpha-\beta} \varepsilon_{t}
$$

$\mathcal{Y}_{t}=$ Aggregate production level of the economy at time $(\mathrm{t})$.

$\mathcal{A}_{t}=$ Factor productivity (total) at time (t).

$\mathcal{K}_{t}=$ Real stock of capital at time (t).

$\mathcal{H}_{t}=$ Stock of human capital at time ( $\left.\mathrm{t}\right)$.

$L_{t}=$ Employed labor force at time (t).

$\alpha \& \beta=$ Output elasticities.

$\varepsilon_{t}=$ Error term.

As this study attempts to investigate for the effects of FDI on the economic growth, therefore Equation [1] is transformed into Equation [2]

$$
\mathcal{G D} \mathcal{P}_{t}=\alpha_{0}+\alpha_{1} F D I_{t}+\alpha_{2} I N F_{t}+\alpha_{3} L A B_{t}+\varepsilon_{t}
$$

$\alpha_{0}=$ Intercept. 
$\mathcal{G D \mathcal { P }}=$ Gross domestic product.

$\mathcal{F D} \mathcal{J}=$ Foreign direct investment inflows.

$\mathcal{J N} \mathcal{F}=$ Inflation measured at consumer price index (CPI).

$\mathcal{L} \mathcal{A B}=$ Employed labor force.

$\varepsilon_{t}=$ Error term.

$\alpha_{1}, \alpha_{2}, \alpha_{3}=$ Coefficients.

\section{Empirical Results}

This section gives an in-depth view of the analytically dragged results on account of various techniques.

\subsection{Descriptive Statistics}

The results of descriptive statistics appear in Table 3. The mean value of GDP appears to be the lowest in the range of all of the right and left sided variables. However, standard deviation of employed labor force is the highest.

Skewness, being a measure for the symmetry and asymmetry is at the position of right skewed for all of the independent variables. On account of the peakness or either flatness of data in contrast to the normal distribution, statistical computations on account of the model of Kurtosis give information that FDI and INF are leptokurtic that are high peaked or long tailed. Rest of the variables' interpretation of Kurtosis is to be platykurtic that is short-tailed and flat. The Jarque-Bera test of normality exercised in this research indicates that, of the four variables (right sided and left sided) GDP and LAB are normally distributed.

Table 3. Descriptive Statistical Analyses

\begin{tabular}{ccccc}
\hline Computation & GDP & FDI & INF & LAB \\
\hline Mean & 5.13 & 15.36 & 61.51 & 34060.27 \\
Median & 4.70 & 18.27 & 38.00 & 30190.00 \\
Maximum & 9.00 & 525.00 & 214.41 & 57579.81 \\
Minimum & 1.70 & -204.11 & 7.40 & 19879.00 \\
Std. Dev. & 1.95 & 102.93 & 53.48 & 11172.40 \\
Skewness & 0.11 & 2.64 & 1.08 & 0.68 \\
Kurtosis & 1.94 & 15.64 & 3.37 & 2.30 \\
Jarque-Bera & 2.07 & 336.60 & 8.59 & 4.26 \\
Probability & 0.35 & 0.00 & 0.01 & 0.11 \\
Sum & 220.64 & 660.70 & 2645.01 & 1464592 \\
Sum Sq. Dev. & 159.9098 & 444983.8 & 120155.6 & $5.24 \mathrm{E}+09$ \\
\hline
\end{tabular}

\subsection{Pair-wise Correlation Matrix}

The strength of the relationship between the variables, both dependent and independent, is diagnosed by the mean of construction of pair wise correlation matrix. It is portrayed in statistical values in Table 4 . However, the matrix shows that INF and LAB are moderately correlated with one another and rest of the variables are found to have weak correspondence with each other.

Table 4. Pair-wise Correlation Matrix

\begin{tabular}{lllll}
\hline$\downarrow$ Variables $\rightarrow$ & GDP & FDI & INF & LAB \\
\hline GDP & 1.00 & & & \\
FDI & -0.09 & 1.00 & & \\
INF & -0.012 & -0.23 & 1.00 & \\
LAB & -0.19 & -0.29 & 0.55 & 1.00 \\
\hline
\end{tabular}

\subsection{Unit Root Test}

The time series data is usually found encompassing through the state of existence of unit root that is the problem of non stationarity. In order to have a check on the existence of unit root, ADF test is worked-with for getting desired information. Table 5 indicates that all the variables turn out to be stationary at first difference intercept. This finding indicates that the null hypothesis that is "there is a unit root" is rejected at this state of position. 
Table 5. Augmented Dickey-Fuller (ADF) Test Results

\begin{tabular}{cccc}
\hline Variables & $t$-Statistics & Probability & Conclusion \\
\hline GDP & $-9.96^{*}$ & 0.00 & $\mathrm{I}(1)$ \\
FDI & $-5.80^{*}$ & 0.00 & $\mathrm{I}(1)$ \\
INF & $-6.15^{*}$ & 0.00 & $\mathrm{I}(1)$ \\
LAB & $-6.96^{*}$ & 0.00 & $\mathrm{I}(1)$ \\
\hline
\end{tabular}

* rejection of null hypothesis at $1 \%$ level of significance

\section{4 Unrestricted Cointegration Rank Test}

In employing Johansen Juselius test of cointegration, one of the developments that this research brings forward is the trace of long-run likelihood relation between the variables opted in the study. The results of the diagnostic test appear in Table 6. The results indicate to disprove the null hypothesis that there is no cointegrating vector and approve the alternate hypothesis of the existence of long-run likelihood at 1 cointegrating equation at 5 percent level of significance.

Table 6. Unrestricted Cointegration Rank Test (Maximum Eigen value)

\begin{tabular}{ccccc}
\hline Hypothesized & & Max-Eigen & 0.05 & \\
\hline No. of CE(s) & Eigen value & Statistic & Critical Value & Prob.** \\
None ${ }^{*}$ & 0.702 & 48.519 & 27.584 & 0.000 \\
At most 1 & 0.389 & 19.737 & 21.131 & 0.077 \\
At most 2 & 0.256 & 11.828 & 14.264 & 0.117 \\
At most 3 & 0.063 & 2.632 & 3.841 & 0.104 \\
\hline
\end{tabular}

Max-eigen value test indicates 1 cointegrating eq. (s) at the 0.05 level

* denotes rejection of the hypothesis at the 0.05 level

**MacKinnon-Haug-Michelis (1999) p-values

\subsection{Normalized Cointegration Coefficients}

Table 7 represents the direction and effects of independent variables on the dependent variable. The use of Johansen Juselius technique of co-integration in an attempt for exploring long-run relationship represents that all the right sided variables, that are FDI, INF and LAB are affecting GDP in positive. On account of FDI, the results show that 1 Million USD change in FDI accounts for 32.9 percent changes in GDP ratio. Thus, this study though captures large range of data that is perhaps not used by the earlier researchers, stands in line with the empirical findings of Khan and Khan (2011) and Hye et al. (2010).

Pakistan welcomes FDI in true letter and spirit just to enhance the level of investment and to get on to the problem of rising prices and unemployment, as suggested by Baharumshah and Thanoon (2006). The results found in terms of FDI, towards GDP are highly significant. In case of LAB the results of the study, though insignificant, but reflect positive effects on GDP. The interplay of LAB and FDI altogether with GDP is tested for the first time in this study as to justify the commonly withheld belief that higher is the labor force participation, higher is supposed to be the GDP growth. The results show that addition of 1 thousand workers in entire labor force participation lead to change GDP by 107.18 percent.

This is indeed unusual findings of this study that inflation variable posts positive repel to GDP. GDP spells outward to be at 4.9 percent of positive change on account of 1 percent change in rate of inflation (CPI). This can be justified by the fact that as higher interest rate is accompanied with higher output level (The LM Curve); thereby higher growth level of economy is to have associations with higher rate of inflation rate, perhaps low peaked. Thought the statistical state of inflation variable is insignificant, however is linked positive to GDP on a ground that too low but upward trend in the price level of the economy is not that harmful to the aggregate demand of the economy. On parallel grounds this adapted rate of inflation keeps on accelerating production due to the increased level of confidence on part of producers who practice a persistent rise in their selling price of goods and services with negligible effects on the demand.

Table 7. Normalized Cointegration Coefficients

\begin{tabular}{cccc}
\hline Variables & Coefficients & Standard error & $t$-statistics \\
\hline FDI & 32.9 & 3.94 & $8.35^{*}$ \\
INF & 4.90 & 3.55 & 1.38 \\
LAB & 107.18 & 144.82 & 0.74 \\
\hline
\end{tabular}

* Rejection of null hypothesis at $1 \%$ level of significance 


\subsection{Short-run Dynamics}

The possibility of short-run relationship is traced through the run of ECM. Table 8, in this respect highlights the value of 0.01 on account of the constant of ECM. This indicates for the correction of 10 percent of the disequilibrium every year as well as appears in the significant range on account of $t$ - statistic. Results on short-run analysis indicate that INF and LAB of last year and two years back have negative effect on GDP. Apart from this, on account of FDI, the effects are traced to be positive towards GDP and do possess short-run relationship. The same findings came up by Hye et al. (2010), Borensztein (1998), Levine and Renelt (1992) in term of short-run effects of FDI on GDP but in negative direction, unlike this study. The results are found to be significant on account of FDI (two years back) and on LAB of last year and perhaps significant. Rests of the findings are with low $t$-value that show of their insignificance standings.

Table 8. Short Run Relationship Dependent variable= GDP

\begin{tabular}{cccc}
\hline Independent variables & Coefficients & Standard error & $t$-statistics \\
\hline Constant & -0.010 & 0.003 & $-3.33^{*}$ \\
D(GDP (-1)) & -0.537 & 0.172 & $-3.12^{*}$ \\
D(GDP (-2)) & -0.077 & 0.151 & -0.51 \\
D(FDI (-1)) & 0.001 & 0.005 & 0.20 \\
D(FDI (-2)) & 0.008 & 0.003 & $2.67^{*}$ \\
D(INF (-1)) & -0.010 & 0.010 & -1.00 \\
D(INF (-2)) & -0.003 & 0.009 & -0.33 \\
D(LAB (-1)) & -0.250 & 0.120 & -0.29 \\
D(LAB (-2)) & -0.040 & 0.140 & -0.30 \\
EC (CointEq1) & -0.080 & 0.260 & \\
& R-squared: 0.54 & & \\
\end{tabular}

* Rejection of null hypothesis at $1 \%$ level of significance

\subsection{Granger Causality}

The test build up by Granger (1969) defines for the causality amongst the variables found in the equation that is regressed for the fetch up of empirical results. In general $x$ is granger-cause to $y$, if and only if $y$ is predicted by the mean of greater accuracy in terms of the use of $x$, instead if value of $x$ is not used and vice versa. Table 9 helps in having a clear sight on the fact that there runs causality among FDI and GDP, perhaps unidirectional. Same pattern of causality is found on account of LAB and GDP. However, neither INF to GDP nor GDP to INF have a causality relationship among one another. It is so due to not disproving of the null hypothesis of no causality.

Table 9. Granger Causality

\begin{tabular}{ccc}
\hline Null Hypothesis: & F-Statistic & Prob. \\
\hline FDI does not Granger Cause GDP & 2.85 & 0.07 \\
GDP does not Granger Cause FDI & 0.29 & 0.74 \\
INF does not Granger Cause GDP & 0.49 & 0.61 \\
GDP does not Granger Cause INF & 0.57 & 0.56 \\
LAB does not Granger Cause GDP & 3.90 & 0.02 \\
GDP does not Granger Cause LAB & 0.78 & 0.46 \\
INF does not Granger Cause FDI & 0.68 & 0.50 \\
FDI does not Granger Cause INF & 0.10 & 0.89 \\
LAB does not Granger Cause FDI & 0.20 & 0.81 \\
FDI does not Granger Cause LAB & 0.44 & 0.64 \\
LAB does not Granger Cause INF & 0.83 & 0.44 \\
INF does not Granger Cause LAB & 0.50 & 0.60 \\
\hline
\end{tabular}

\section{Policy Recommendations and Conclusion}

This section elaborates for the conclusion of the study and the suggestion for the better take up of the viable policy options. 


\subsection{Policy Recommendation}

Pakistan has an important standing position in terms of the available natural and physical resources particularly in South Asian Region. This study clarifies and signifies the association and effects of FDI to GDP of Pakistan. There is an immense need to encounter internal economic unrest in terms of political conflicts, internal security situations, law and order and energy crises that are perhaps turmoil for the international business(s) to have sufficient and viable footings in Pakistan economy. Unless these footings are strengthened, it would merely be like an un-materialized dream of economic growth and overall prosperity within the state.

These recommendations appear to be strong afterwards there is known that GDP is positive in response to FDI. On the supplementary note, labor force participation rate as possesses positive effects on GDP further seeks attention of the government to the fact that along with FDI inflows, it should not be a think-up of transforming towards capital intensive techniques. It is because labor force participation altogether contributes to enhance GDP, perhaps in positive. So the policies supposed to be made while adapting new technologies in reflection of FDI should not be of being damaging to labor force participation rate. It is because employment growth, in terms of higher labor force participation is also as important to economic growth as is FDI.

The politicians must join heads for taking the country to masses on accord of choosing for the unanimous solution to these confusions and problems. It is indeed not possible to be got done in short span of time. However, hoping for the best and prosperous future is only dependent upon the fact that policies should be made for bettering-off internal socioeconomic situation. That is why the time now is to bring up the policies on the ground in terms of their practical implementation. This will surely enhance the FDI base that in turn will strengthen the economic growth stature of a country that is perhaps a sign of current economic health and indeed a reflection for the future success of a country.

\subsection{Conclusion}

Economic growth is the indicator that reflects the position of current standings of the economy in the row of the other countries of the world. FDI is always a key determinant of economic growth, indeed. In compliance to that, the effects of FDI on economic growth vary from country to country. Insight on the GDP growth statistics of Pakistan shows for a persistent rising trend, somehow or the other, since from the most depressed state in fiscal year 2008-2009. As forecasted by IMF that economic growth of Asian Countries will tend to be at 6.8 percent, in compliance to that, Pakistan's economic growth is projected at 5.1 percent for the next year that is 2015 . On account of FDI inflows to Pakistan, Switzerland is a source of consistently rising FDI inflows in past endeavors. However, significant fall of the investment is found from Australia, Behrain, Germany, Malaysia and Saudi Arabia.

The study examined the trends and effects of variables through the capture of data based on 43 number of yearly observation that is from 1972 to 2014. On part of the results of the study, the study went through descriptive statistical analysis and pair wise correlation matrix. The test of cointegration is run as defined by Johansen and Juselius as well as ECM for the short-run and long-run dynamics. The study found GDP positively affected by direct foreign investment. FDI possessed relationship with GDP in both short-run and long-run time period. However, INF and LAB also had positive venture to GDP. Unidirectional causality is also found running between GDP and FDI.

It is indeed a significant contribution that this study has brought up which is in line with the results that have been expressed on account of labor force participation and that of economic growth rate, together with FDI inflows, as of being positive. This reflects the fact that when and as FDI inflows are exerted in transforming GDP to tend towards positive move, labor force participation also is explained in the same angle of posing effects on economic growth.

\section{References}

Ali, S. (2014). Foreign capital flows and economic growth in Pakistan: An empirical analysis. World Applied Science Journal, 29(2), 193-201. http://dx.doi.org/10.5829/idosi.wasj.2014.29.02.1372

Ali, S. S. (1993). Management of foreign and dependency of Pakistan (Unpublished M.Phil Thesis), Quaid-e-Azam University, Islamabad, Pakistan.

Baharumshah, A. Z., \& Thanoon, M. A. (2006). Foreign capital flows and economic growth in East Asian countries. China Economic Review, 17(1), 70-83. http://dx.doi.org/10.1016/j.chieco.2005.09.001

Bénassy-Quéré, A., Fontagné, L., \& Lahrèche-Révil, A. (2001). Exchange-rate strategies in the competition for attracting foreign direct investment. Journal of the Japanese and International Economies, 15(2), 178-198. 
Bengoa, M., \& Sanchez-Robles, B. (2003). Foreign direct investment, economic freedom and growth: new evidence from Latin America. European Journal of Political Economy, 19(2003), 529-545. http://dx.doi.org/10.1016/S0176-2680(03)00011-9

Borensztein, E., De Gregorio, J., \& Lee, J. W. (1998). How does foreign direct investment affect economic growth? Journal of International Economics, 45(1), 115-135. http://dx.doi.org/10.1016/S0022-1996(97) 00033-0

Chaudhry, I. S., Malik, A., \& Faridi, M. Z. (2010). Exploring the causality relationship between trade liberalization, human capital and economic growth: Empirical evidence from Pakistan. Journal of Economics and International Finance, 2(8), 175-182.

Dickey, D. A., \& Fuller, W. A. (1979). Distribution of the estimators for autoregressive time series with a unit root. Journal of American Statistical Association, 74(366), 427-431. http://dx.doi.org/10.1080/01621459. 1979.10482531

Duasa, J. (2007). Malaysian foreign direct investment and growth: Does stability matters? Journal of Economic Cooperation, 28(2), 83-89.

Farkas B. (2012). Absorptive capacities and the impact of FDI on economic growth. DIW Berlin Discussion Paper No. 1202. http://dx.doi.org/10.2139/ssrn.2038182

Granger, C. W. (1969). Investigating casual relations by econometrics models and cross-spectral methods. Econometrica, 37(3), 424-438.

Hassan, S., \& Karim, M. Z. A. (2007). Private and Public Investment in Malaysia: Substitutability or Complementarity? The IUP Journal of Applied Economics, 6(2), 17-32.

Hassan, S., Nor'Aznin A. B., \& Hussin, A. (2014) Analysis of FDI Inflows into China from ASEAN-5 Countries: A Panel Cointegration Approach. Journal of Economic Cooperation and Development, 35(3), 1-28.

Hassan, S., Othman, Z., \& Harun, M. (2014). Ownership Structure Variation and Firm Efficiency. Asian Social Science, 10(11), 233-241. http://dx.doi.org/10.5539/ass.v10n11p233

Hassan, S., Othman, Z., \& Karim, M. Z. A. (2011). Private and Public Investment in Malaysia: A Panel Time-Series Analysis. International Journal of Economics and Financial Issues, 1(4), 199-210.

Herzer, D., Klasen, S., \& Nowak-Lehmann, D. F. (2006). In search of FDI-led growth in developing countries. American Institute of Economic Research, Discussion papers (No. 150).

Hye, Q. M. A., Shahbaz, M., \& Hye, A. (2010). Foreign capital inflow and economic growth nexus: A case study of Pakistan. Journal of Applied Economics, 9(1), 16-26.

Johansen, S., \& Juselius, K. (1990). Maximum likelihood estimation and inference on co-integration with application for the demand for money. Oxford Bulletin of Economics and Statistics, 52(2), 169-210. http://dx.doi.org/10.1111/j.1468-0084.1990.mp52002003.

Khan, M. A. (2007). Foreign direct investment and economic growth: the role of domestic financial sector. Pakistan Institute of Development Economics, PIDE Working Paper Series, (No.18).

Khan, M. A., \& Khan, S. A. (2011). Foreign direct investment and economic growth in Pakistan: A sectoral analysis. Pakistan Institute of Development Economics, PIDE Working Paper, (No. 67).

Kobrin, S. (2005). The determinants of liberalization of FDI policy in developing countries: 1991-2001. Transnational Corporation, 14(1), 67-103.

Levine, R., \& Renelt, D. (1992). A sensitivity analysis of cross country growth regression. American Economic Review, 82(4), 942-963.

Lipsey, R. (1999). The location and characteristics of U.S. affiliates in Asia. NBER Working Paper Cambridge, MA (No. 6876).http://dx.doi.org/10.386/w6876.

Mehmood, K. A., \& Faridi, M. Z. (2013). Factors of garnishing across the border investments. Pakistan Journal of Commerce and Social Science, 7(3), 588-602.

Mosley, P. (1980). Aid savings and growth revisited. Oxford Bulletin of Economics and Statistics, 42(1), 79-95.

Okodua, H. (2009). Foreign direct investment and economic growth: Co-integration and causality analysis of Nigeria. The African Financial Journal, 11(1), 54-73.

Onakoya A. B. (2012). Impact of foreign direct investment on economic growth in Nigeria: A disaggregated 
sector analysis. Journal of Economics and Sustainable Development, 3(10), 66-75.

Papanek. (1972). The effects of aid and other resource transfers on saving and growth in less developed countries. Economic Journal, 82(327), 934-950.

Papanek, G. F. (1973). Aid, foreign private investment, saving and growth in LDC. Journal of Political Economy, 81(1), 120-130.

Rana, P. B. (1987). Foreign capital, exports, savings and growth in the Asian region. Saving and Development, 11(1) 5-28.

Solow, R. M. (1956). A contribution to the theory of economic growth. Quarterly Journal of Economics, 17(1), 65-94.

Thomas, H., Li, X., \& Liu, X. (2008). Ownership structure and now product development in transnational corporation in China. Transnational Corporations, 17(2), 17-44.

Tsai, P-L. (1994). Determinants of foreign direct investment and its impacts on economic growth. Journal of Economic Development, 19(1), 137-162.

Tung, S., \& Cho, S. (2001). Determinants of regional investment decisions in China: an econometric model of tax incentive policy. Review of Quantitative Finance and Accounting, 17(2), 167-185.

Zhang, K. H. (2001). How does foreign direct investment affect economic growth in China? Economics of Transition, 9(3), 679-693. http://dx.doi.org/10.1111/1468-0351.00095

\section{Copyrights}

Copyright for this article is retained by the author(s), with first publication rights granted to the journal.

This is an open-access article distributed under the terms and conditions of the Creative Commons Attribution license (http://creativecommons.org/licenses/by/3.0/). 